\title{
Correction to: Evaluation of Liver Function Tests and Risk Score Assessment to Screen Patients for Significant Liver Disease Prior to Bariatric and Metabolic Surgery
}

\author{
Antony Antypas ${ }^{1} \cdot$ Andrew Austin $^{2} \cdot$ Sherif Awad $^{2} \cdot$ David Hughes $^{2,3} \cdot$ Iskandar Idris $^{1,2}$ (D) \\ Published online: 30 July 2020 \\ (C) The Author(s) 2020
}

Correction to: Obesity Surgery (2020) 30:2840-2843
https://doi.org/10.1007/s11695-020-04486-4

The name of author Antony Antypas was misspelled in the original article. It is correct here.

Open Access This article is licensed under a Creative Commons Attribution 4.0 International License, which permits use, sharing, adaptation, distribution and reproduction in any medium or format, as long as you give appropriate credit to the original author(s) and the source, provide a link to the Creative Commons licence, and indicate if changes were made. The images or other third party material in this article are included in the article's Creative Commons licence, unless indicated otherwise in a credit line to the material. If material is not included in the article's Creative Commons licence and your intended use is not permitted by statutory regulation or exceeds the permitted use, you will need to obtain permission directly from the copyright holder. To view a copy of this licence, visit http://creativecommons.org/licenses/by/4.0/.

Publisher's Note Springer Nature remains neutral with regard to jurisdictional claims in published maps and institutional affiliations.

The online version of the original article can be found at https://doi.org/ $10.1007 /$ s11695-020-04486-4

Iskandar Idris

Iskandar.idris@nottingham.ac.uk

1 School of Medicine, University of Nottingham, Nottingham, UK

2 University Hospitals of Derby And Burton Foundation Trust, Derby, UK

3 Division of Medical Sciences \& Graduate Entry Medicine,School of Medicine, University of Nottingham, Royal Derby Hospital Centre, Uttoxeter Road, Derby DE22 3DT, UK 